\title{
Islam, State and Modernity: Mohammed Abed al-Jabri and the Future of the Arab World
}

Ziad Eyadat, Francesca M. Corrao, \& Mohammed Hashas, eds. New York: Palgrave MacMillan, 2018. 320 pages.

Mohammed Abed al-Jabri (1935-2010) is one of the most original Arab philosophers, thinkers, and social theorist of recent times. Al-Jabri, who held the post of Professor of Philosophy at University of Rabat (Morocco), is the author of over 30 books - mostly on Arab Islamic thought-of which the best-known are works like Critique of Arab Reason (1984-2001, 4 vols.), Arab Political Reason (1990), An Introduction to the Noble Quran (2006), and Democracy, Human Rights and Law in Islamic Thought (2009). Though al-Jabri is "one of the most original and multifaceted philosophers and intellectuals of our time" (p. xii), commands considerable influence on the Arab world, and is regarded as significant and influential as the Iranian Abdolkarim Soroush, the Egyptian Hasan Hanafi, and the French Mohammed Arkoun, he has remained insufficiently recognized in the West or Euro-American scholarship. The volume under review, first of its kind in English, is thus dedicated to exploring and highlighting varied aspects of al-Jabri's thought, philosophy, and impact.

Edited by Zaid Eyadat (University of Jordan), Francesca M. Corrao, and Mohammed Hashas (both from LUISS, University of Rome), this work analyzes and highlights "how al-Jabri has been a fertile intellectual force in the contemporary Arab world" (15). The volume consists of fourteen 
chapters divided into two parts: Part I is titled 'Al-Jabri's Reconstruction of Arab-Islamic Thought' (Chapters 2-8), and Part II is titled 'Politics, Ethics, and the Future of the State in the Arab World' (Chapters 9-14). These are bookended by a foreword (ix-xiii) by Abdou-Filali Ansary and a biographical appendix. The work acts as an "introductory volume for more future work" to be done in the English language "on this far-sighted Arab-Muslim philosopher" (15). What follows below is a survey of some selected chapters from each part of the book, so as to get an impression of what is contained, discussed, and explored in this volume.

In the introduction (Chapter 1), the editors situate and contextualize the philosophy and legacy of al-Jabri within the broader perspective of contemporary Arab thought. They argue that the volume is focused on an aspect of Arab philosophy, dealing "with a philosophical project that classifies Arab intellectual history and contributes to contemporary Arab political philosophy" (8).

Massimo Companini (Chapter 2) explores the work of al-Jabri and Hasan Hanafi vis-à-vis Ibn Khaldun and Ibn Rushd, and tries to find a "Path to Modernity" (41). His main argument is that al-Jabri contends for the "Averroistic" interpretation of the "future of Arab-Islamic culture", which is both "rationalistic and democratic" (25) and thus fits aptly within the present political trend. Abdul Karim Barghout et al. (Chapter 3) focus on the Syrian thinker George Tarabishi's (d. 2016) Critique of the Critique of Arab Reason (1996), by expounding their disagreements on Arab history. The differences between al-Jabri and Tabarishi remain over the theoretical frameworks or methodological grounds, not on historical substance.

These and other chapters of this part revolve mostly around al-Jabri's Critique. However, Mariangela Laviano (Chapter 6) provides a "preliminary overview of al-Jabri's introductory work on the Qur'an" (2006), in which alJabri "gives a systematic rereading of the Qur'an and its phenomenon" and provides a "chronological order of decent of revelation (tartīb al-nuzūl), and not the common order/ sequence, i.e., tartìb al-tilāwa/ tartīb al-mușhaf" (114). For Laviano, al-Jabri considers the Qur'an a Text which needs to be "studied in its context, but at the same time taking into consideration its sacredness" (114-115); such a "rational approach helps the reader to look at some Qura'nic verses,..., in the light of historical context" and thus gives "more attention to human rights and rebuilding the Arab world" (120).

Part II of this volume is concentrated on exploring "the question of politics and ethics in a-Jabri's examination of the history of ideas of the Arab-Islamic world." It highlights his significance and relevance in the pre- 
and post-Arab Spring eras in MENA as well as considers his thought's possible influence on the "future of the Arab state" (17). Mohsine El Ahmadi (Chapter 9) reflects on the aspects of al-Jabri's political thought by focusing on the question of state and religion through an exposition of his Critique of Arab Political Reason (1984) and Religion, State, and Implementation of Sharia (1996). It clearly reveals al-Jabri's "intellectual position on Islam and political power" (173), which is mainly "decisive in the reconstruction of modern thought based on the reason and democracy" (172). Ahmadi also focuses on "specific critique of Islamic historicity" (176), and concludes that "Historicity, epistemology, and secularism are dialectical foundations of al-Jabri's views on Arab-Islamic reform" and thus represent a "major development in the transformation of Arab-Islamic political thought" (180).

Zaid Eyadat and Hanadi Riyad (Chapter 12) focus on al-Jabri's "effort and his contribution to Arab intellectual thought" by analyzing, critically, his Arab Ethical Reason (2006) - a work yet-untranslated and so unavailable to an English audience. This chapter aims to introduce it to the Western reader while suggesting a "way forward from al-Jabri's work towards a more creative and peaceful Arab Reason".

The last chapter, "The Arab Possible State: From al-Tahtawi to alJabri," by Mohammed Hashas (Chapter 14), reinvigorates the possibility of a "modern Arab state" based on "Arab-Islamic tradition", despite various "obstacles encountering its realization", as manifested, most recently, in the Arab Spring (272). Hashas deliberates on "three Arab political discourse levels”, viz. 'Arab Renaissance avant-gardists', 'Arab Nationhood Discourse', and 'State Discourse Around Arab Spring. Later, he elaborates the state concept in al-Jabri's thought, concluding that al-Jabri calls for a "democratic modern state", neither secular nor liberal, which will be based on the three principles of "human rights, the rule of law and rationality" (290).

Written by specialists at various stages of their careers, and keeping in view the richness and diversity of topics, Islam, State and Modernity is a significant contribution to exploring the various aspects of al-Jabri's thought, philosophy, and legacy for a wider readership, on topics ranging from Arab-Islamic thought to the state, politics, ethics, education, and the Quran phenomenon. It will prove helpful to students and scholars in a wide range of disciplines, ranging from Middle East Studies to Philosophy.

Tauseef Ahmad Parray Assistant Professor, Islamic Studies, Higher Education Department Jammu \& Kashmir, India 